Article

\title{
An Integrated Urban Flood Vulnerability Index for Sustainable Planning in Arid Zones of Developing Countries
}

\author{
Carlos Salazar-Briones *, José Mizael Ruiz-Gibert, Marcelo A. Lomelí-Banda and \\ Alejandro Mungaray-Moctezuma * \\ Facultad de Ingeniería, Universidad Autónoma de Baja California, Mexicali, Blvd. Benito Juárez, S/N, \\ Mexicali C.P. 21280, Mexico; mizael.ruiz@uabc.edu.mx (J.M.R.-G.); lomeli.marcelo@uabc.edu.mx (M.A.L.-B.) \\ * Correspondence: csalazar86@uabc.edu.mx (C.S.-B.); alejandro.mungaray@uabc.edu.mx (A.M.-M.)
}

Received: 31 December 2019; Accepted: 14 February 2020; Published: 24 February 2020

check for updates

\begin{abstract}
Floods are among the most recurring and devastating natural hazards, impacting human lives and causing severe economic damage. Urbanization can increase the risk of flooding due to increased peak discharge and volume. Over arid urban areas of developing countries, flood disaster management is reactive, responding to prevailing disaster situations, mainly because of the lack of budget, equipment, facilities, and human resources. The approach required in a new city requires a different operative planning process, ruled by different kinds of specific indicators to be incorporated in the sustainable planning process. This study focuses on an approach to assess flood vulnerability as a planning tool using an integrated flood vulnerability index (FVI) with variables that are accessible in developing countries and arid urban areas. The research took place in the city of Mexicali, Baja, California. México. This index was determined by coupling the variables of three components: social, economic, and physical. The FVI reflects the status of an urban scale's vulnerability. Variables were obtained from government data for the social and economic components, and a hydrological and hydraulic model approach as a physical component. The correlation of each variable to the flood was taken into account by using a general linear transformation. GIS was used as a tool for the development of spatial analysis. The results showed the spatial distribution of vulnerability at an urban district scale. It was found that $55 \%$ of the population is exposed to a vulnerability above the average value of the urban area. Integrating all the components will help decision-makers to implement strategies to improve the resilience of the area by attending the needs of the particular component that is more vulnerable.
\end{abstract}

Keywords: flood vulnerability index; urban scale; GIS analysis; planning tools; integrated model

\section{Introduction}

According to several authors [1-5], floods are among the most recurring and devastating natural hazards, impacting human lives and causing severe economic damage throughout the world. It is understood that flood risks will not subside in the future, and with the onset of climate change, flood intensity and frequency will threaten many regions of the world [6]. The increase in impervious areas as a result of urban uncontrolled growth and development generates an increase in runoff that can cause flooding and influence the quality of the water collected [7].

During intense heavy rainfalls, floods present a rapid rise of water along with a stream or low-lying sections [8]. This type of flood is commonly known as a flash flood. Because of the rapidity and suddenness of their onset and their high intensity over a relatively small geographic area, flash floods pose a significant threat to human systems worldwide [9]. Urbanization in basin areas can be added as 
an additional significant control: it can increase the risk of flooding due to increased peak discharge and volume and decreased time to peak [10,11]. Urban watersheds, on average, lose $90 \%$ of storm rainfall to runoff [12].

Climate change causes an acceleration in the frequency of extreme events [13]. Socio-economic changes in large parts of the developing world will increase the exposure and vulnerability of people and infrastructure to floods and droughts in the near future [14]. The increase in precipitation, as well as the frequency and magnitude of inland flooding, expedites the erosion of roads and bridges and makes them more vulnerable to failures [15]. Urban areas contain significant concentrations of infrastructure in the form of residential, commercial, and industrial structures, as well as transportation, telecommunications, energy and water treatment and delivery facilities. Floods damage infrastructure by the force of floodwater, debris and sediment associated with flooding, or by landslides triggered by floods [14].

This scenario implies that urban areas, in particular, suffer from a comparatively high flood vulnerability due to their high population number and density, multiple economic activities, and many infrastructure and property values that, in turn, interfere with the natural infiltration processes [6]. Globally, economic losses from flooding exceeded \$19 billion in 2012 [16]. In this scenario, scholars researching urban sustainability and resilience, as processes determined by a context-specific combination (or lack) of capacities, focus on (dynamic) attributes of resources and assets, and urban planners draw upon options to respond to the disruptions and stresses they encounter (resilience) while pursuing their livelihoods, businesses, and urban planning and management goals (sustainability) [17].

In most developing countries, flood disaster management is mostly reactive, responding to prevailing disaster situations. To change from a reactive to proactive response to increase the effectiveness of management and reduce losses of life and properties, disaster management requires more participation from various governments, non-governmental and private agencies, and public participation. It involves more effort and time, more budget, equipment, facilities, and human resources, which leads to the integration of flood disaster management for both long and short term activities [2], which often prevents developing countries from adequately managing their planning instruments. Public participation, supporting the population's commitment to and providing guidance for urban planning actions, is therefore of utmost importance in the development process and transformation of cities for the future. This approach to a new city requires a different operative planning process, ruled by different kinds of specific indicators to be incorporated into the planning process by the municipalities and local administration [18].

In arid regions, the study of floods becomes a difficult task due to the variability of rainfall, lack of vegetation, and a stream network poorly defined and dominated by zero flows during most of the year [19]. Floods in arid areas are caused by high-intensity rainfall over the small catchment; urban areas in arid regions are especially vulnerable to these events [20]. These events are also known as flash floods and are distinguished from "ordinary" floods by their time scale and intensity [21]. Since they can be developed in periods of hours or less, they are particularly dangerous for urban areas due to the lack of preparedness. There will be a continued need for research, for revising emergency management practices, and for the utilization of wise practices at the local level to develop disaster-resistant communities. Success in all these endeavors, however, will depend on financial resources, political will, social justice, local initiative, and personal responsibility [22].

The description of so-called natural disasters has changed in recent decades, from a naturalistic perspective to one that takes into account the vulnerability component. Consequently, disasters are not inevitable since they are frequently associated with a lack of planning and prevention measures [23], therefore vulnerability is considered as the extent of the harm which can be expected under certain conditions of exposure, susceptibility, and resilience [24].

Usually, flood assessment and management policies include the physical vulnerability of the infrastructure exposed during the flood [25]. Even though this physical vulnerability can characterize the susceptibility of a specific flood to cause damage, it does not asses the vulnerability of its inhabitants 
and their social context [26]. Therefore, vulnerability can be assessed using physical, economic, and social factors, combining different domains as well as quantitative with qualitative data [27]. Indeed, a practical and systematic way of managing periodic flood disasters requires mapping flood-susceptible areas and understanding potential flood-triggering factors [28].

Researchers such as Balica and others [29,30], had developed methodologies for flood vulnerability index (FVI) calculations based on social, economic, and physical components using 71 indicators. However, some of these indicators may be redundant or do not influence the results, so it is possible to perform an analysis to establish the most relevant indicators in order to establish parsimonious usage of the FVI [31]. These indexes are processed for different geographic scales and are as valid as the quality of the data obtained for their calculations, and this represents a problem in the developing countries we're monitoring. Gouging operations are often discarded for their high cost. Besides, the lack of financial resources to prepare for and prevent floods can pose a crucial constraint on developing countries' efforts to increase their climate resilience. Linked to this are gaps in technical know-how, skills, and data, which all influence the way a country responds to natural disaster risks [32].

The development of a community-based flood vulnerability index for urban flooding through using local components and indicators is essential in generating a localized flood vulnerability that depicts a more realistic scenario of vulnerability and resilience indexes in a local, national and international setting [33]. For aid engineers and planners, by investigating the risk of floods and presenting the results in a suitable format as the integration between the geographical information system (GIS) and hydrologic/hydraulic models, it can be useful to generate flood maps [34]. For that reason the GIS will be used as a tool for developing the spatial analysis in this research.

This study focuses on an approach to assess a flood vulnerability index; the indicators used show the variables affecting flood vulnerability in the urban area of Mexicali, Baja California, México. This index was determined by coupling three components: social, economic, and physical. The FVI is an indicator-based index that reflects the status of a scale's flood vulnerability. The paper aims to assess flood vulnerability, integrating government statistical data for social and economic components, and the hydrologic and hydraulic data obtained by the model created by Salazar et al. 2018 as a physical component, consisting of a hydrological model for different return periods, performing Regional Frequency Analysis (RFA) using the L-Moments approach [35]. Lack of monitoring and physical data is generally the weakest component in developing countries; the model integration approach will compensate this weakness, resulting in a quality index that can be used as a planning tool in urban areas with similar characteristics.

\section{Materials and Methods}

\subsection{Methodology}

The composed FVI methodology developed by Balica and Wright. 2010, uses 71 indicators in its calculation. However, it is recognized that some of these indicators may be redundant or have no influence on the results [31]. In this research, a set of normalized variables (indicators) for each AGEB was processed into a numerical index that reflects the status of a region's flood vulnerability. The overall components and variables were selected considering previous research $[29,30]$. These variables were adjusted accordingly to data availability for the urban AGEB scale. The overall FVI components and process are addressed in Figure 1. 


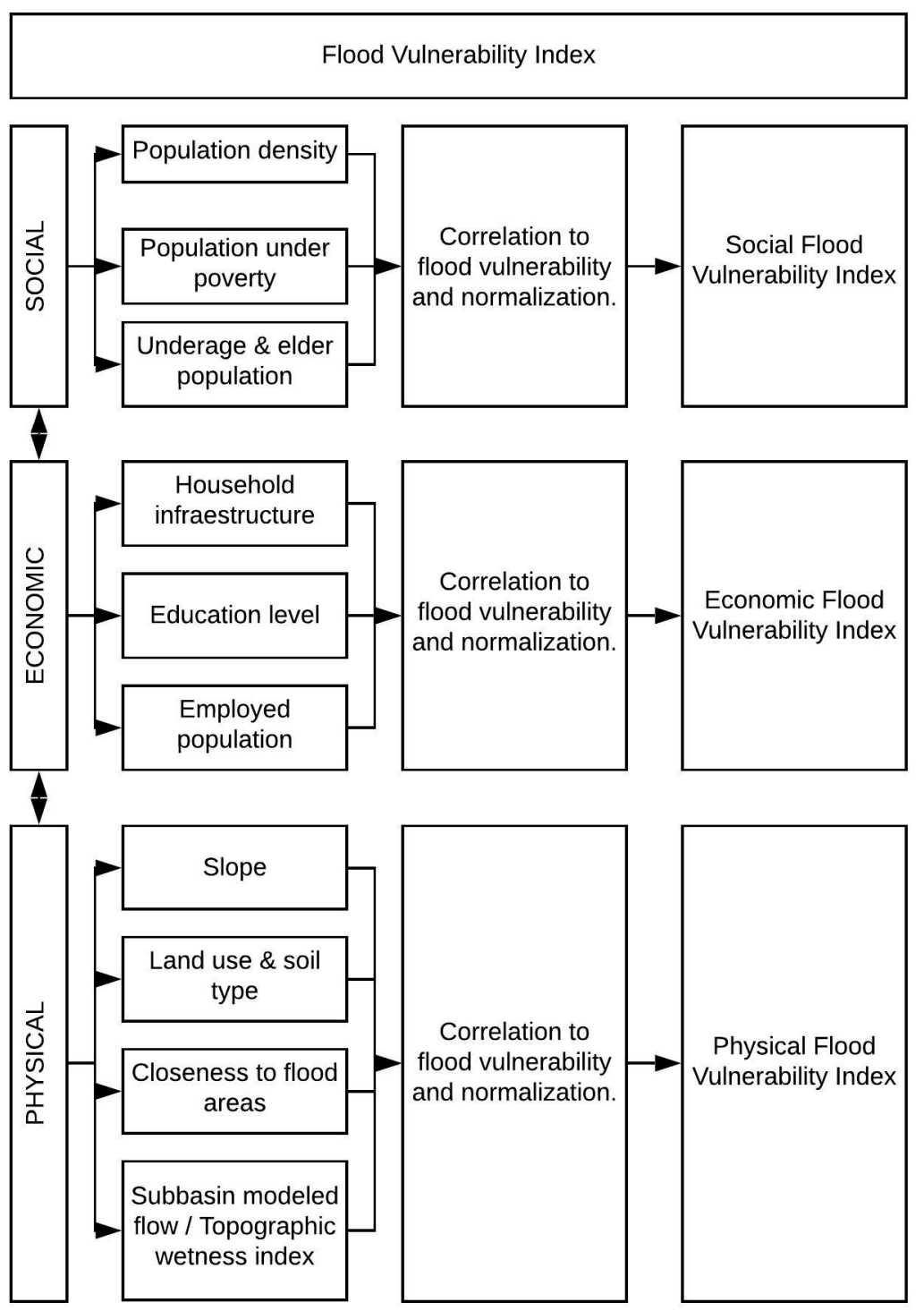

Figure 1. Flood vulnerability components and indicators processing methods.

\subsection{Study Area and Data}

The FVI developed in this research was calculated for the urban area of Mexicali (Figure 2), Baja California, Mexico. According to the data of the National Institute of Statistic and Geography (INEGI by acronym in Spanish), referred to in the Population and Housing Census of 2010, the total population in Mexicali was 936,826 inhabitants, representing $29.7 \%$ of the total population of the State of Baja California. The surface of its sub-basin of the New River that flows into the border with the United States is $2066.69 \mathrm{~km}^{2}$ and has an average slope of $9.61 \%$. The length of its mainstream is $47.270 \mathrm{~m}$, and its slope is $3.063 \%$. It is worth mentioning that this study considers the section of the New River with a length of $14.17 \mathrm{~km}$, located geographically at the UTM-WGS84-Z11N coordinates at $3,608,660.30 \mathrm{~m}$ north and $645,613.80 \mathrm{~m}$ west [35].

In the State of Baja California, the peninsula $\mathrm{N}$ of latitude $28 \mathrm{~N}$, lies on the equatorward margin of the planetary jet stream at the transition between the North American Mediterranean climatic zone of winter precipitation and summer drought, and desert climates that span the remainder of the peninsula [36]. In the case of Mexicali city, considering its latitudinal location $\left(\mathrm{s} 32^{\circ} \mathrm{N}\right)$, and geographical position in Baja California, its climate is arid, with only $75 \mathrm{~mm}$ of average annual rainfall and extreme thermal conditions: maximum temperatures over $50{ }^{\circ} \mathrm{C}$ in the summer months and minimum temperatures lower than $0{ }^{\circ} \mathrm{C}$ in the winter [37]. 


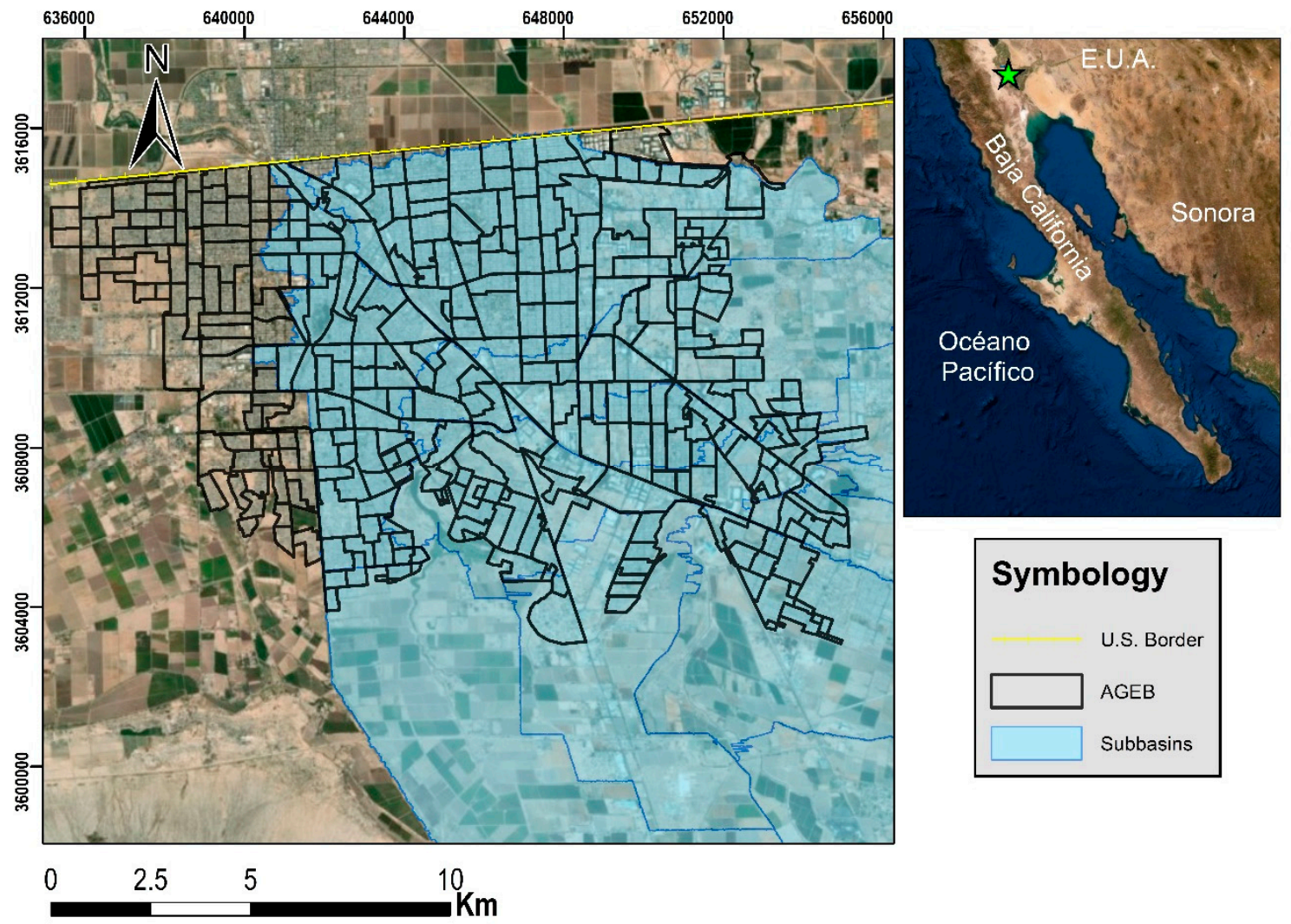

Figure 2. Study area and selected primary geostatistical area (AGEB) scale for vulnerability calculation.

Unlike other researchers, the level of analysis was not carried out at the sub-basin level, but at an urban scale, using the primary geostatistical area (AGEB by the acronym in Spanish), due to the availability of both social and economic data available in Mexico. The AGEB constitutes the basic unit of the National Geostatistical Framework, which is a unique and national system designed by INEGI to correctly cross-reference the statistical information of the surveys with the corresponding geographical locations. It is classified into two types: urban and rural. The first is the geographical area occupied by a set of blocks, perfectly delimited by streets and avenues; this type of AGEB is assigned in geographical areas of localities that have a population equal to or greater than 2500 inhabitants [38].

\subsection{Vulnerability Components}

Following the identification of the study area and scale of the indicator as an AGEB unit, the composed FVI was calculated taking into account three components that drive the vulnerability to floods.

\subsubsection{Social Component}

The INEGI performs a population census all around the country, recording data mostly related to the population and their households. Collected data is classified and can be publicly accessed at various scales, including AGEB. Since the intention of this census is mostly demographic information, it is hard to relate this data to the most commonly used flood indicators.

Population density is one is the most commonly used variables for the social vulnerability index. This variable was calculated according to the AGEB population within its area, and it was processed using the INEGI population database along with GIS tools to calculate the area. Areas with a high density will correlate positively to physical vulnerability.

The INEGI census classifies the number of people by age and gender; this was useful for identifying the underage and elderly population within each AGEB. The population considered in this 
classification was people under 14 years old and people over 60 years old. This variable correlates positively with vulnerability.

Population under poverty is another commonly used variable for the social components of vulnerability [29], as it is assumed that wealthy areas have enough resources to cope with the impacts of floods. However, this variable is not directly measured in all countries since it is relative to its social context; instead of through this research, it was obtained by using employment and access to medical services. Populations under this condition were considered for this indicator as it correlates positively to the physical vulnerability.

The indicators used for the social components are named in Table 1.

Table 1. Social vulnerability component indicators.

\begin{tabular}{|c|c|c|}
\hline VARIABLE & Processing Method & REFERENCES \\
\hline Population density & $\begin{array}{l}\text { Aged population within } \\
\text { the area }\end{array}$ & $\begin{array}{l}\text { Balica, A. Fekete 2009, } \\
\text { Hajar Nasiri and Shahram } \\
\text { Shahmohammadi-Kalalagh 2013, } \\
\text { Schmidtlein et al. 2008, } \\
\text { Christoph Sebald 2010. }\end{array}$ \\
\hline $\begin{array}{l}\text { UNDERAGE AND ELDER } \\
\text { POPULATION }\end{array}$ & $\begin{array}{l}\text { AGEB population under } \\
14 \text { years old and over } \\
60 \text { years old }\end{array}$ & $\begin{array}{l}\text { Balica, A. Fekete 2009, } \\
\text { Schmidtlein et al. 2008, } \\
\text { Christoph Sebald 2010, } \\
\text { P. Fernandez et al. 2016. }\end{array}$ \\
\hline POPULATION UNDER POVERTY & $\begin{array}{l}\text { AGEB unemployed } \\
\text { population and population } \\
\text { with medical service access }\end{array}$ & $\begin{array}{l}\text { Balica, A. Fekete 2009, } \\
\text { Schmidtlein et al. 2008, } \\
\text { Christoph Sebald 2010, } \\
\text { P. Fernandez et al. } 2016 .\end{array}$ \\
\hline
\end{tabular}

\subsubsection{Economic Component}

The economic component illustrates the income and wealth of the region of study [32]. At larger scales, economic variables related to flood vulnerability are much more diverse than the ones available at an AGEB. Data available for this component within an AGEB scale are limited; however, information such as employment and unemployment, household infrastructure characteristics, and education can be obtained as economic variables.

Unemployed population is not a direct variable that is measured for the AGEB unit, however, the economically active population is measured, therefore, the difference between the total adult AGEB population and economically active population was considered as unemployed. This variable relates positively to the economic component.

Education is another variable available for the AGEB; it has been proven that a population with higher education is more prepared to cope with flood events. Therefore, this variable relates negatively to vulnerability.

Household infrastructure information is limited on an AGEB scale, however, INEGI counts houses with bare soil floors as living under extreme poverty conditions. Although is a rare case for the urban area, it was considered as an indicator that relates positively to vulnerability.

Table 2 shows the variables used for the component.

Table 2. Economical component indicators.

\begin{tabular}{cll}
\hline \multicolumn{1}{c}{ VARIABLE } & \multicolumn{1}{c}{ Processing MeTHOD } & \multicolumn{1}{c}{ ReFerences } \\
\hline & & Balica, Hajar Nasiri and Shahram \\
& & Shahmohammadi-Kalalagh 2013, \\
Pifference between Adult & Hajar Nasiri 2016, \\
population and economically & P. Fernandez et al. 2016, \\
& active population. & Muhammad Tauhidur Rahman \\
& & Adel S. Aldosary Kh Md \\
& Nahiduzzaman Imran Reza 2016 \\
\hline
\end{tabular}


Table 2. Cont.

\begin{tabular}{|c|c|c|}
\hline VARIABLE & Processing Method & REFERENCES \\
\hline Education & $\begin{array}{l}\text { Population with a superior } \\
\text { education degree }\end{array}$ & $\begin{array}{l}\text { Balica, A. Fekete 2009, } \\
\text { Schmidtlein et al. 2008, } \\
\text { Christoph Sebald 2010, } \\
\text { P. Fernandez et al. 2016, } \\
\text { Muhammad Tauhidur Rahman } \\
\text { Adel S. Aldosary Kh Md } \\
\text { Nahiduzzaman Imran Reza } 2016\end{array}$ \\
\hline HOUSEHOLD INFRASTRUCTURE & $\begin{array}{l}\text { Number of households with } \\
\text { bare soil in the AGEB }\end{array}$ & $\begin{array}{l}\text { Balica, A. Fekete 2009, Hajar } \\
\text { Nasiri 2016, P. Fernandez et al. } \\
\text { 2016, Ismawaty Nur and Krishna } \\
\text { K. Shrestha } 2017\end{array}$ \\
\hline
\end{tabular}

\subsubsection{Physical Component}

Developing countries face a limitation when it comes to physical data such as historical flood series, streamflow gauges, meteorological stations, and other physical data essential for flood analysis or modeling. However, previous studies such as Salazar et al. [35] have proved that limited data can be compensated for by implementing specialized tools and methods. Therefore, hydrological and hydraulic data were obtained from previous research [35], and processed into the AGEB scale (Table 3). This model was developed to obtain an estimated streamflow design for different return periods, under the scheme of the regional frequency analysis with the L-moments approach. The results of the hydrological and hydraulic modeling of the New River basin were used as inputs to identify the flood zones.

Table 3. Physical component indicators.

\begin{tabular}{|c|c|c|}
\hline VARIABLE & Processing & REFERENCES \\
\hline SLOPE & $\begin{array}{l}5 \times 5 \text { m LIDAR High-resolution } \\
\text { digital elevation model. Mean } \\
\text { slope within each AGEB unit was } \\
\text { processed as an indicator }\end{array}$ & $\begin{array}{l}\text { Balica, Muhammad Tauhidur } \\
\text { Rahman Adel S. Aldosary Kh Md } \\
\text { Nahiduzzaman Imran Reza } 2016\end{array}$ \\
\hline Closeness to inundation area & $\begin{array}{l}\text { Salazar et al. } 2018 \text { identified } \\
\text { inundation area within the New } \\
\text { river, data was obtained as the } \\
\text { nearest distance for each AGEB } \\
\text { unit }\end{array}$ & $\begin{array}{l}\text { Balica, Hajar Nasiri and Shahram } \\
\text { Shahmohammadi-Kalalagh, 2013, } \\
\text { Hajar Nasiri } 2016\end{array}$ \\
\hline TOPOGRAPHIC WETNESS INDEX & $\begin{array}{l}\text { Saiz et al. } 2019 \text { data was proccesed } \\
\text { into each AGEB unit }\end{array}$ & $\begin{array}{l}\text { Pourali et al. 2014, Aksoy et al., } \\
2016\end{array}$ \\
\hline LAND USE \& SOIL TYPE & $\begin{array}{l}\text { Salazar et al. } 2018 \text { identified a } \\
\text { Curved number from land-use } \\
\text { and soil layers within the urban } \\
\text { area. This value was then } \\
\text { processed into the AGEB unit }\end{array}$ & $\begin{array}{l}\text { Balica, Muhammad Tauhidur } \\
\text { Rahman Adel S. Aldosary Kh Md } \\
\text { Nahiduzzaman Imran Reza } 2016\end{array}$ \\
\hline SUB-BASIN STREAMFLOW & $\begin{array}{l}\text { Salazar et al. } 2018 \text { calculated peak } \\
\text { flow for each sub-basin. These } \\
\text { values were then processed into } \\
\text { the AGEB unit }\end{array}$ & $\begin{array}{l}\text { Sarchani and Tsanis, 2019; } \\
\text { Patel } 2009\end{array}$ \\
\hline
\end{tabular}

As seen in the study area, the modeled watershed does not cover the urban area in its entirety. For these areas, a topographic wetness index was processed for each AGEB outside the watershed coverage. The map of TWI, made from a raster data at a $5 \times 5 \mathrm{~m}$ scale, was provided by Saiz et al. 2019 [39]. A mean value was then calculated for each AGEB as a physical indicator. Table 3 shows the variables used for this component.

Rasters elevation data from INEGI were downloaded at a $5 \times 5 \mathrm{~m}$ resolution; LIDAR imagery was processed to obtain a full digital elevation model of the urban area. Using GIS tools, this raster was 
then processed to obtain mean slope within each AGEB. This variable is directly correlated with floods, as more significant slopes result in higher streamflow levels and speed.

Salazar et al.'s [35] study showed the New River been a flood-prone area; thus, the nearest distance from each AGEB to the delimited inundation area was considered as another physical indicator.

Land use and soil type are physiographic hydrological characteristics that drive the amount of flow generated within an area; this can be qualitatively considered using the NRSC curved number. This value was extracted into each AGEB from the previously addressed model.

Finally, the peak flow value was extracted into the AGEB from each of the sub-basins delimited by Salazar et al. (2018). However, since the coverage area of the basin does not cover the full urban area, a topographic wetness index map was used [39] to evaluate the possible flood areas. All physical variables used impact positively on the vulnerability of the component.

Table 3 shows the variables used as well as the processing method used for each one.

\subsection{Normalization and Correlation of Variables}

To compare each variable as an indicator on a 0 to 1 basis, a normalization was made, considering the correlation of each variable to the flood. Therefore, variables that add resilience to the AGEB, such as education, will reduce the vulnerability [40]. Normalized vulnerability variables taking into account this positive or negative correlation were calculated by using a general linear transformation. The formula used for those variables positive related to vulnerability was as follows

$$
Z_{i}=\frac{X_{i}-X_{\min }}{X_{\max }-X_{\min }}
$$

where $Z_{i}$ represents the normalized value of an indicator within that AGEB $i, X_{i}$ is the value of that variable for the same AGEB $i$, and $X_{\max }$ and $X_{\min }$ the maximum and minimum value across all AGEB of that variable.

For those variables with an inverse relationship to vulnerability, normalization was made using

$$
Z_{i}=1-\left(\frac{X_{i}-X_{\min }}{X_{\max }-X_{\min }}\right)
$$

\subsection{Vulnerability Index Calculation}

Once all indicators were normalized within 0 to 1 , for each AGEB, the social, economic, and physical components' vulnerability $\left(V_{s}, V_{e}, V_{f}\right)$ are computed as the arithmetic mean of the indicators that define them $\left(Z_{i}\right)$.

$$
\begin{aligned}
& V_{s}=\frac{1}{n} \sum_{i=1}^{n} Z_{i} \\
& V_{e}=\frac{1}{n} \sum_{i=1}^{n} Z_{i} \\
& V_{f}=\frac{1}{n} \sum_{i=1}^{n} Z_{i}
\end{aligned}
$$

Sub-component variables can be combined within each category by using either a geometric mean or a weighted mean with weights inversely proportional to the impact uncertainty level.

Vulnerability assessment has been expressed different by many authors. Balica et al. [29,30] classify the different variables of each component into an equally weighted expression in terms of exposure, susceptibility and resilience. Other vulnerability studies, such as Neumann et al. [40], explore the use of different schemes for FVI calculation, such as equal weights and a weighting scheme according to the number of variables in each component and random weights, results showed there is a good correlation between results obtained with both methods. 
However, in a more recent study by Carrao et al. [41], seven schemes were analyzed, resulting in a non-weighted scheme having the best performance. Their outcomes suggest that the non-weighted scheme is more stable and robust than other models, and best representative of the unknown regional vulnerability rankings.

As this is a first approach for vulnerability assessment, the composite FVI was calculated as an arithmetic mean of the three components, as follows.

$$
F V I=\frac{\left(V_{s}+V_{e}+V_{f}\right)}{3}
$$

\section{Results and Discussion}

To solve the problems derived from the optimization of the development plan, urban planners look for a variety of ways to search the best option based on the forecasts of the outcome of each alternative analyzed, modeling this as a tool of vital importance between urban development, risk management, services ecosystem, environment, and social welfare. This is necessary to pass from a disciplinary approach either, from the social sciences or of the natural sciences, as has traditionally been carried out, to a holistic approach, that integrally solves urban planning processes, achieving an improvement in the population's quality of life, reducing the risk of flood and contributing to the protection of the environment. This is why in this research - the economic, physical, and social variables-were given the same weight, to act as a bridge between the different approaches, and to make it possible to make decisions on the different stakeholders and the community.

Results were assessed for each of the components, identifying the most vulnerable areas for each one and for the overall FVI. A total of 329 AGEB units corresponding to the urban area were used as a scale unit to calculate the FVI index.

\subsection{Social Vulnerability}

The social vulnerability mean value over all the AGEB units was identified as 0.41 . Assessing the data corresponding to Figure 3, it was found that 167 of the AGEB units present a vulnerability that is above the mean value. These AGEB units present the higher population concentration, and the most vulnerable value found was 0.75 .

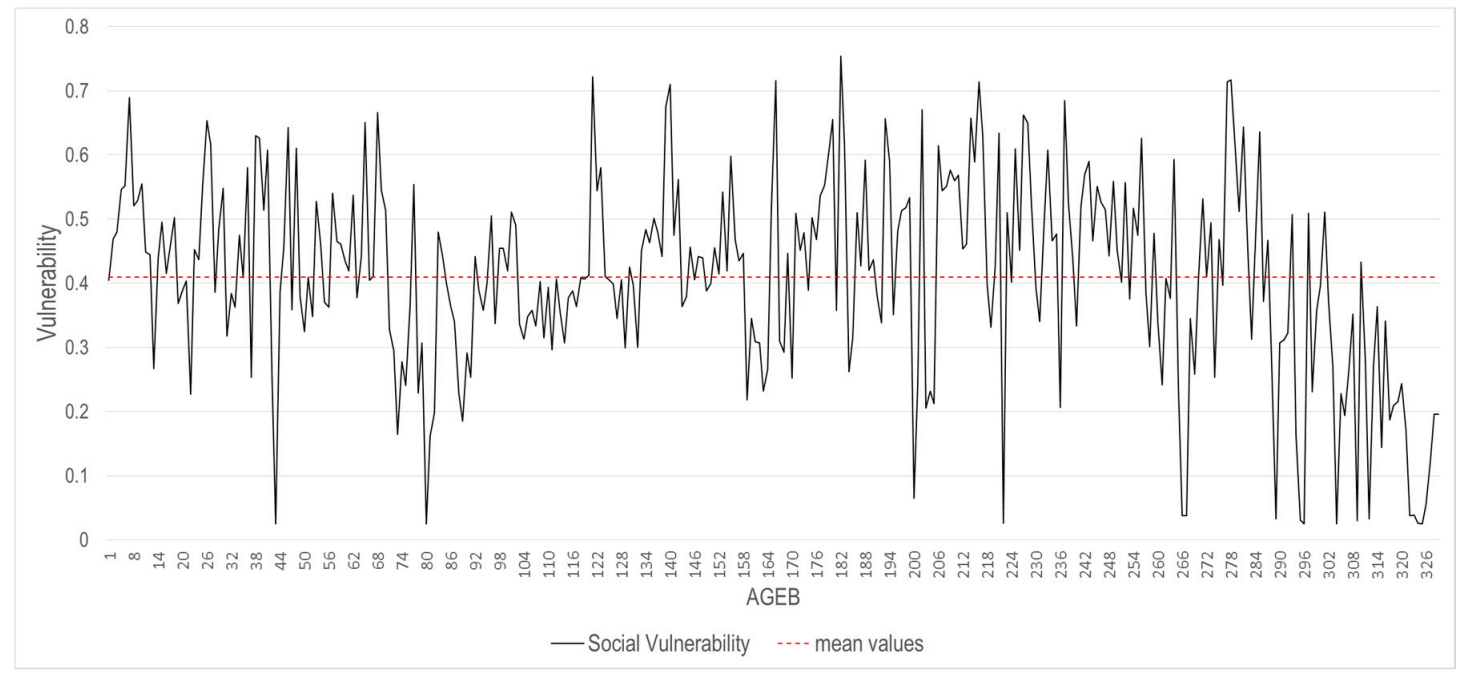

Figure 3. Social vulnerability values for the studied AGEB.

The most vulnerable variable for this component was the underage and elderly population, followed by population density and finally poverty variable. Figure 4 shows the spatial distribution of this component. Most vulnerable AGEBs are located in the perimeter of the urban area. 


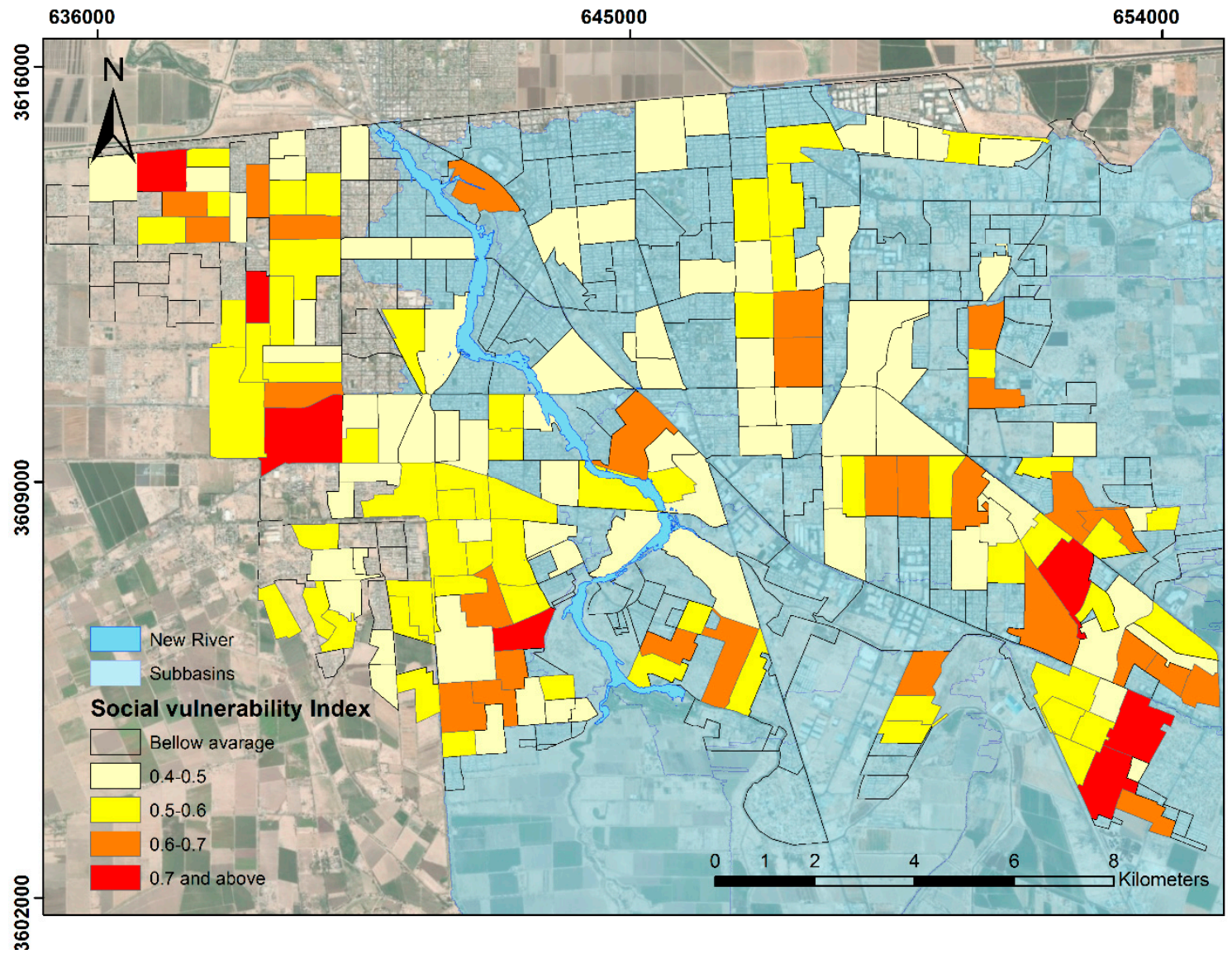

Figure 4. Spatial distribution of the AGEBS with a social vulnerability above the average value.

\subsection{Economic Vulnerability}

The economic component variables on an AGEB unit scale are limited. However, the component was successfully addressed with the available data, although a future study could implement surveys to account for the lack of data on this scale.

Results showed that the average economic vulnerability is 0.39; this means that 153 AGEB units are affected by a vulnerability above the average (Figure 5 ).

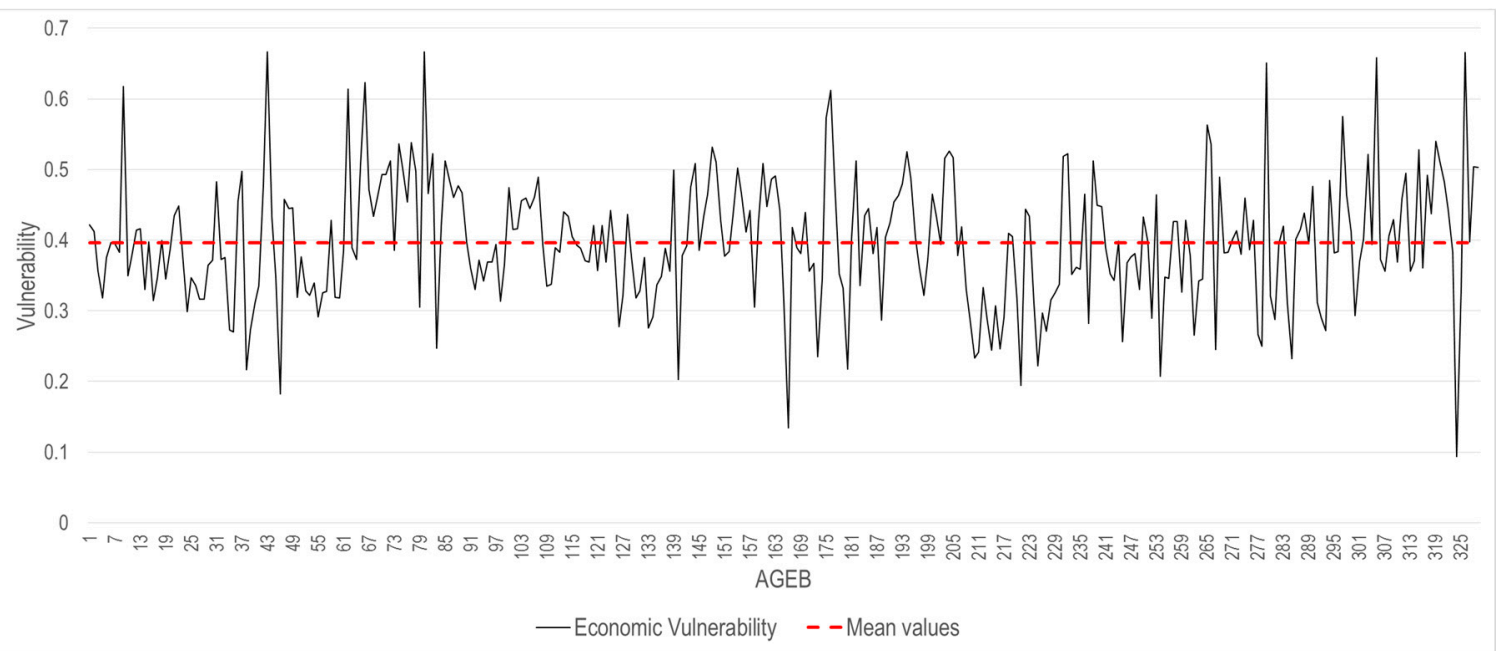

Figure 5. Economical vulnerability values for the studied AGEB. 
This $46 \%$ area affected by a higher vulnerability is mainly related to the employed population variable. However, this does not necessarily mean that all the population is unemployed, as the AGEB data corresponds only to formal activities that include social security. This fact would mean that all informal activities are not considered in the variable as a permanent job. As for the household infrastructure variable, results showed a lower vulnerability, as most of the urban areas of the city are provided with basic services, paved streets and concrete-based edification. The spatial distribution pattern of this component is addressed in Figure 6.

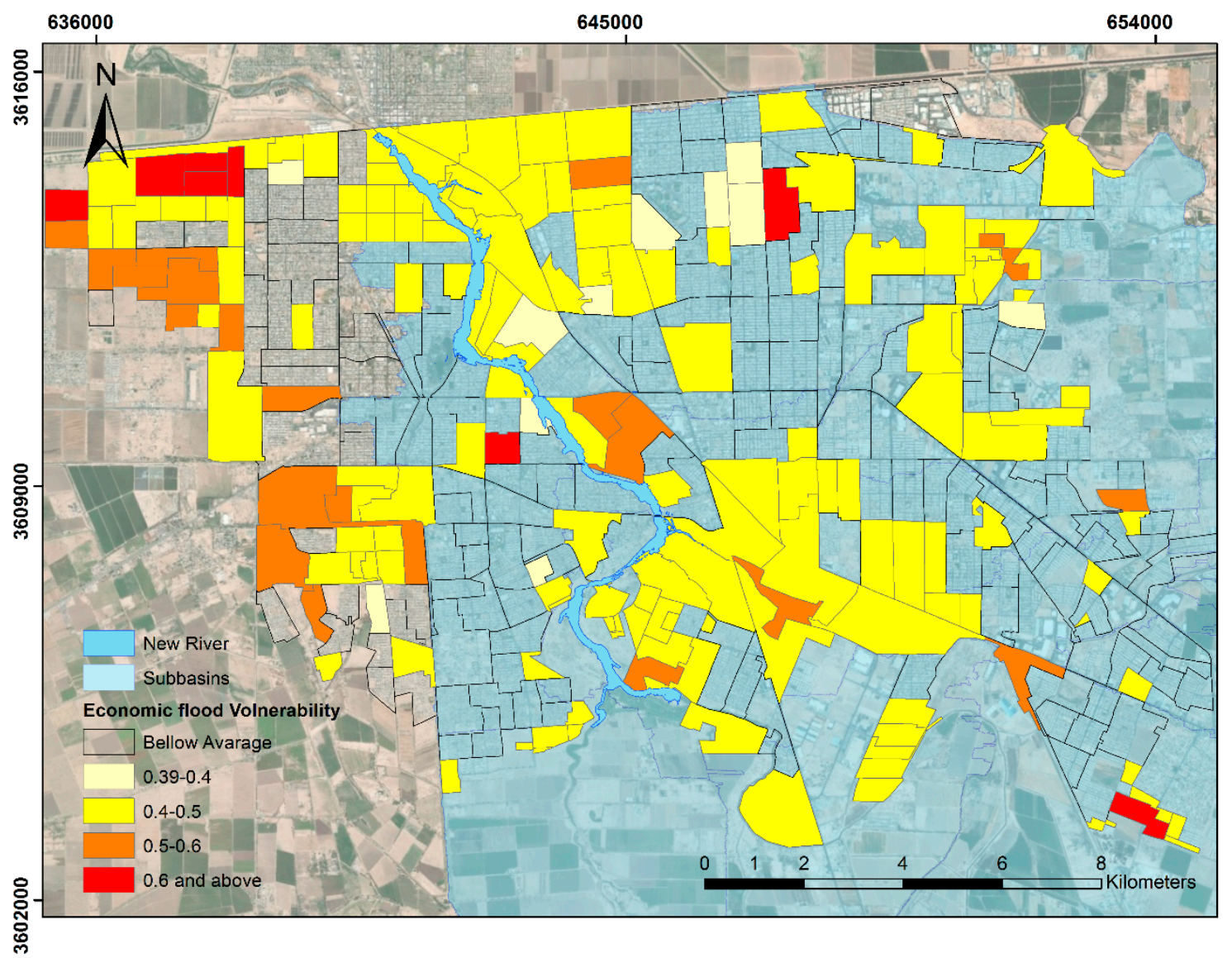

Figure 6. Spatial distribution of the AGEBS with a economic vulnerability above the average value.

\subsection{Physical Vulnerability}

As expected for an urban area within a river basin, the physical vulnerability component, composed mostly by hydrological and hydraulic variables, affects a significant area of the urban area. A total of $65 \%$ of the AGEB units (Figure 7) or a total of 213 presents physical vulnerability values that are above the 0.64 average value. The urban area is affected by the mainstream of the New River, which creates a natural environment for physical vulnerability within its stream. It is essential to state that the new river is the main outlet of the urban drainage system. This factor makes the use of modeled data essential, especially in areas with similar characteristics.

Analyzing the variables, the land use and soil type variable were the most vulnerable. Since this variable was addressed with the $\mathrm{CN}$, it can be appreciated that the lack of vegetation and high concentration of impervious areas is the reason for this high vulnerability. The overall results of the physical vulnerability can be taken into account to define areas where the implementation of projects that promote vegetation areas such as parks or green infrastructure have to be considered in order to improve resilience. 


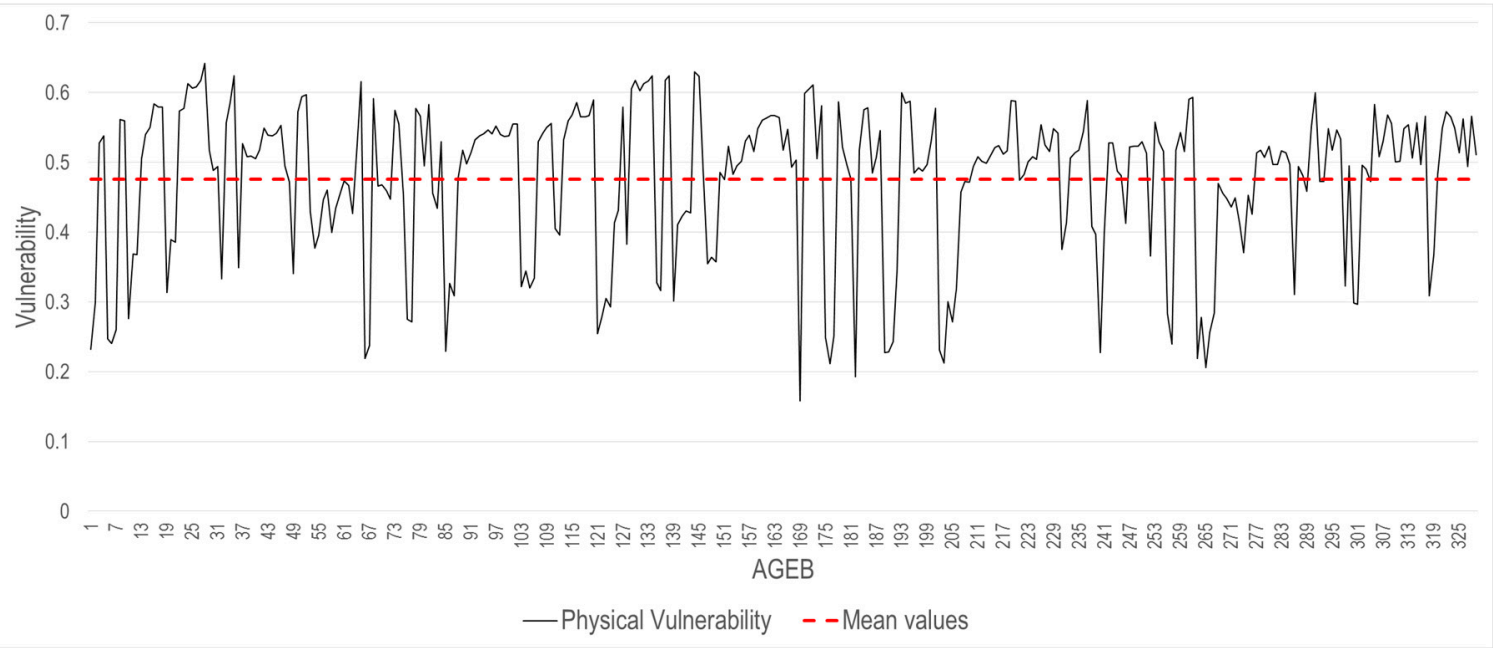

Figure 7. Physical vulnerability values for the studied AGEB.

As seen on the spatial distribution of this component (Figure 8), the influence of the sub-basins affects the AGEB units that are more vulnerable. Those AGEB units close to the river are the most physically vulnerable.

Areas outside the sub-basin influence were analyzed using the TWI. This tool has been used before to identify flood-prone areas. Even though it is a product of the processing of elevation raster data, it can be implemented on areas where hydrological modeling data is not available, or where it is hard to develop a new one due to the lack of monitoring information.

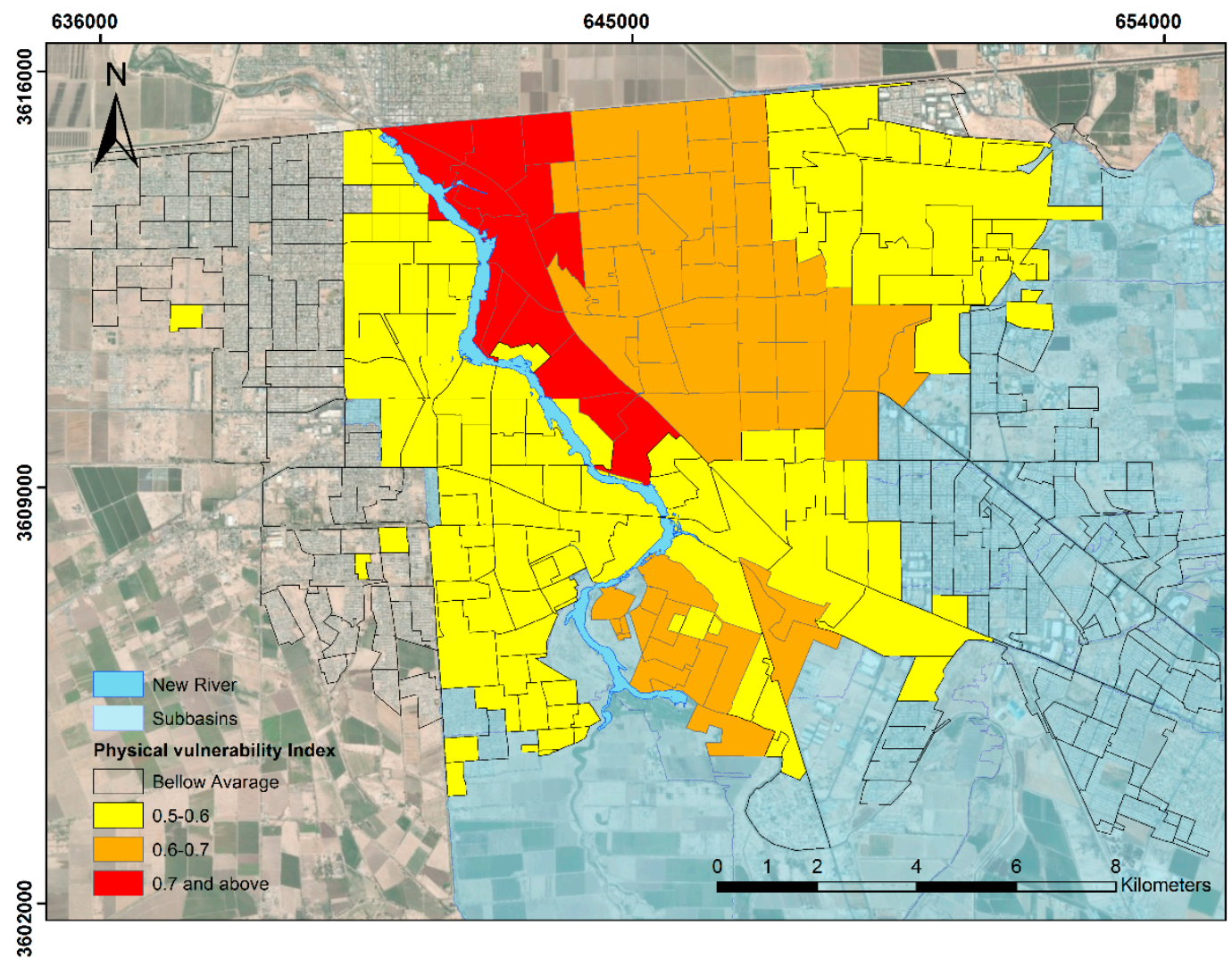

Figure 8. Comparison of the physical vulnerability indicators. 


\subsection{Composed Flood Vulnerability Index}

The composed results of the flood vulnerability index are addressed spatially in Figure 9. AGEB units with higher vulnerable values are located within the boundaries of the sub-basin, delimited by the hydrological model. However, some AGEB units with high values can also be found outside this sub-basin, denoting the importance of using a composed vulnerability index. Although some AGEB units within the reaches of the sub-basin show high physical vulnerability, like those near to the mainstream of the New River, when analyzing the composed FVI map, they do not show the highest vulnerability, mainly due to the economic and social components. As well as this, some highly vulnerable AGEB units can be found far from the mainstream.

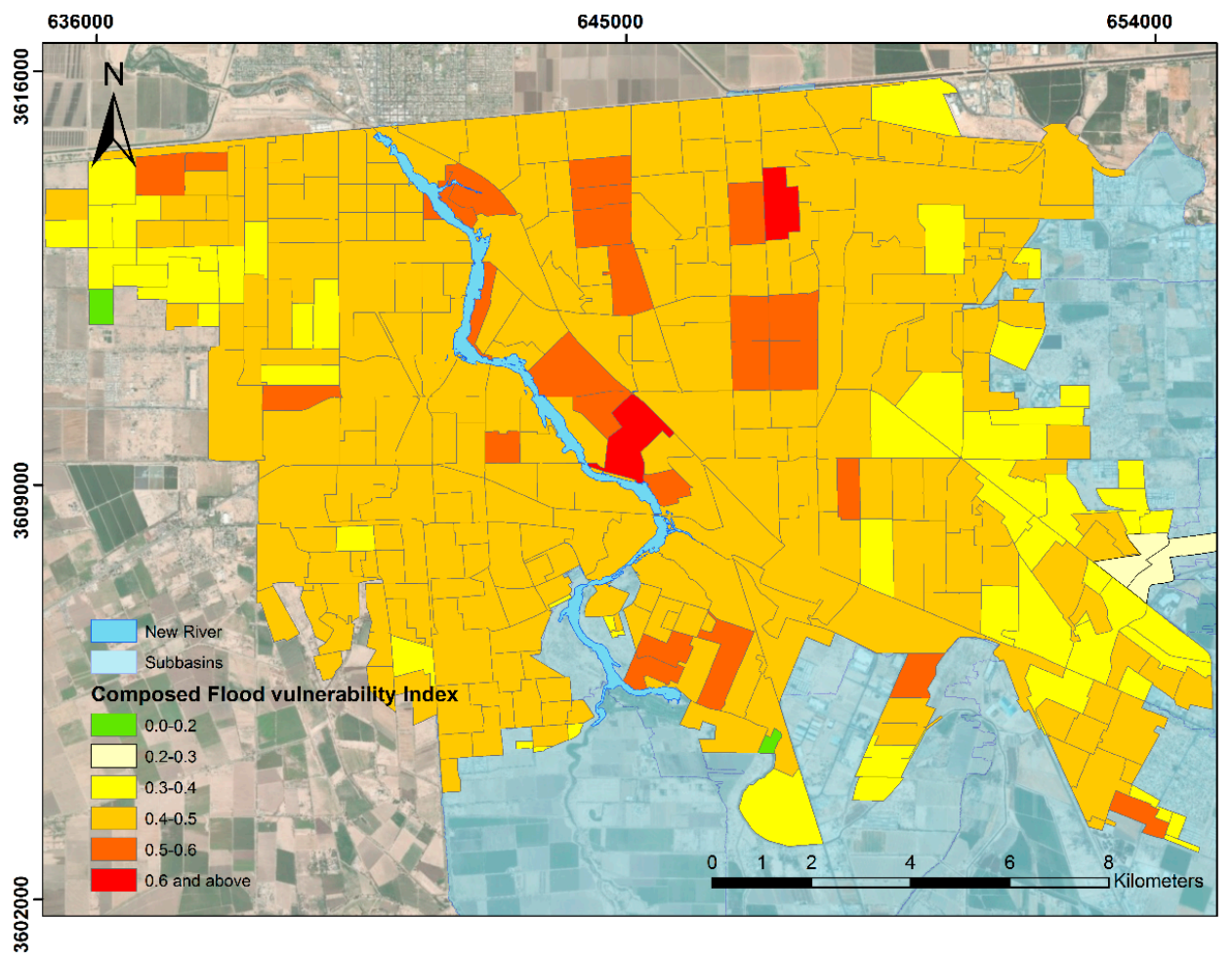

Figure 9. Composed flood vulnerability index for an AGEB scale.

Statistically speaking, the average vulnerability for the composed FVI was 0.42 (Figure 10). A 55\% of the AGEB units are impacted by a vulnerability above the average, with a total of 182 AGEB units and 476,331 inhabitants exposed to flood impacts. These AGEBS are shown in Figure 11.

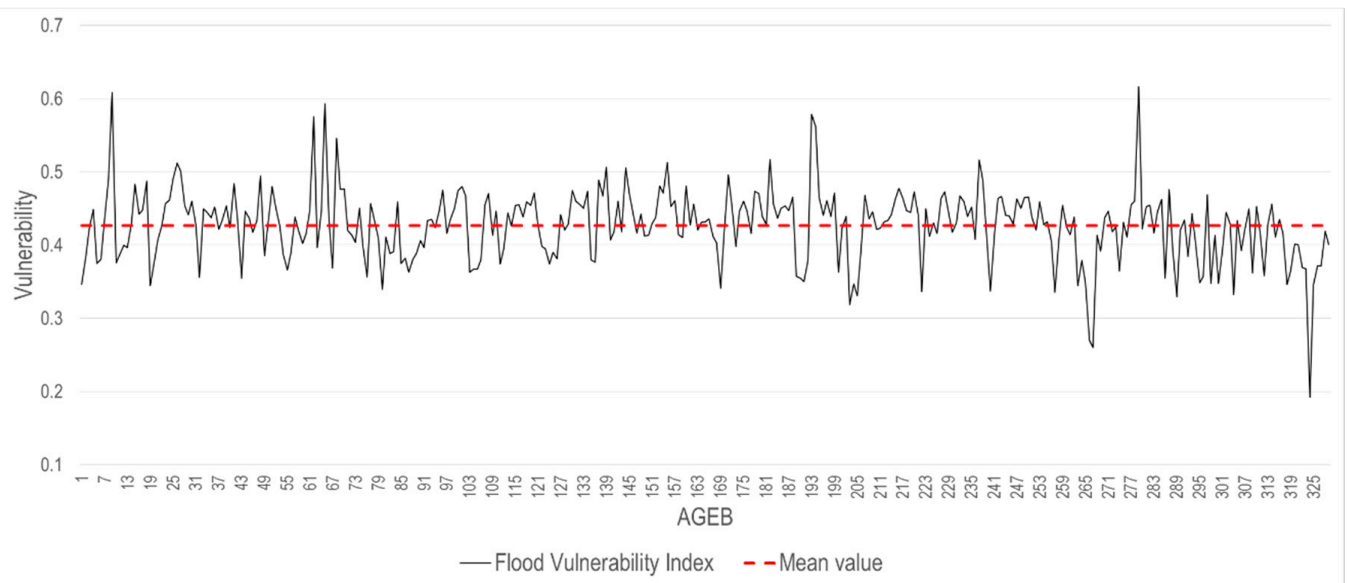

Figure 10. Composed flood vulnerability index values for the studied AGEB. 
As addressed before, the sub-basins' delimitation does not necessarily drive the highest vulnerability, and results show highly vulnerable areas outside the sub-basins. Commonly in developing countries, decision-makers base their developing urban plans accordingly, mainly on demographic and socio-economic components. As proved by the results, these socio-economic components impact drastically on the flood vulnerability within an area. However, the composed results show that the best way to address vulnerability is through the use of multidisciplinary components that include physical component modeling data.

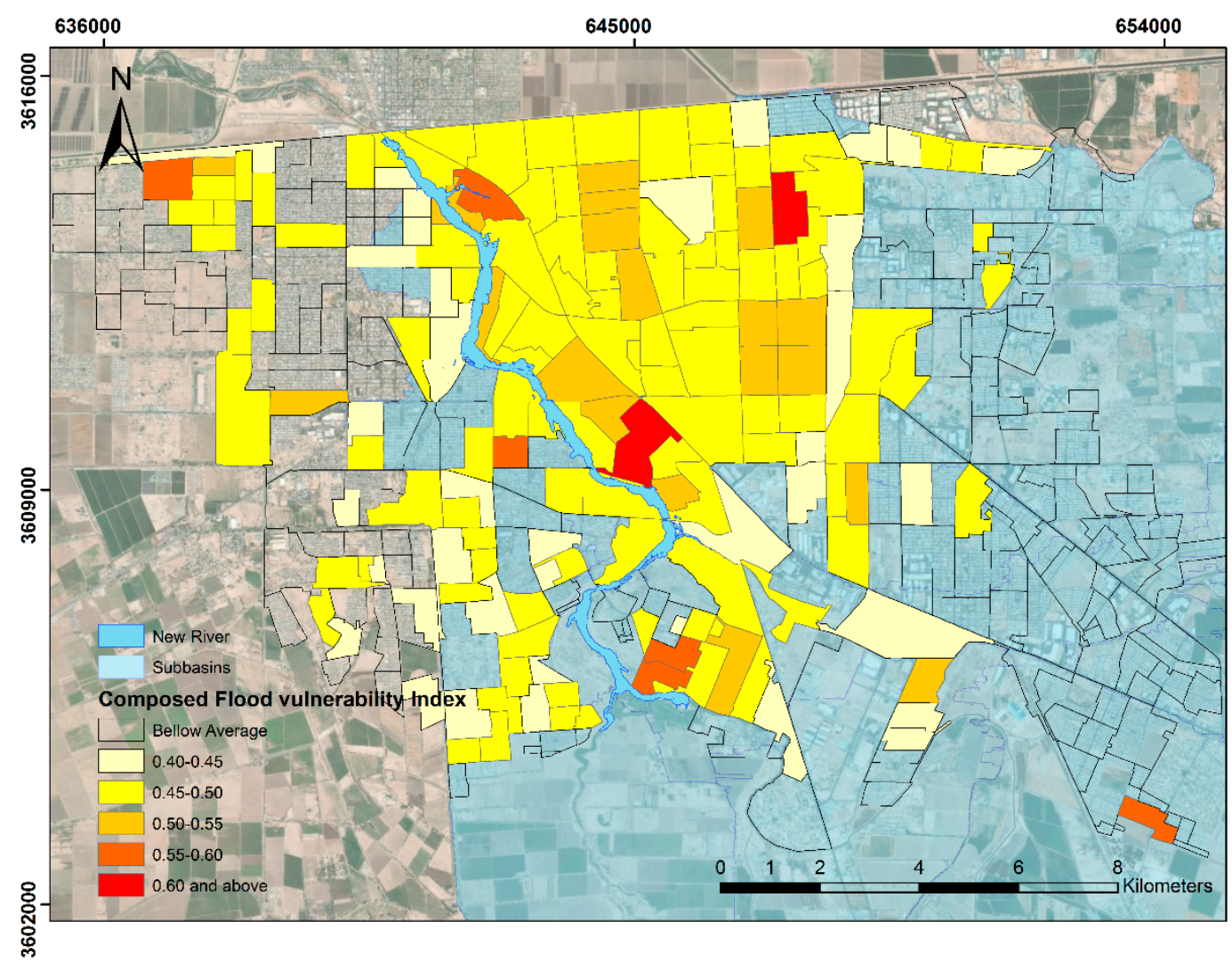

Figure 11. Assessment of AGEB units that showed an anomaly of above the mean vulnerability values.

Finally, Table 4 identifies the three most vulnerable AGEBS within the urban area for each of the components, and also for the composed FVI. Overall, the most vulnerable AGEB, taking into account the composed FVI, was the AGEB coded 0000200017054. This AGEB unit has a population of 3117, and it is also the second highest in terms of economic vulnerability.

Table 4. Most vulnerable AGEB units for each component and the overall composed FVI.

\begin{tabular}{ccc}
\hline \multicolumn{3}{c}{ Most vulnerable AGEB for social component } \\
\hline AGEB code & Vulnerability value & Exposed Population \\
\hline 0200200015594 & 0.75 & 5393 \\
0200200014558 & 0.72 & 3837 \\
$020020001704 \mathrm{~A}$ & 0.71 & 5238 \\
\hline \multicolumn{2}{c}{ Most vulnerable AGEB for economic component } \\
\hline AGEB code & Vulnerability value & Exposed Population \\
\hline 0200200010273 & 0.74 & 3429 \\
0200200017054 & 0.73 & 3117 \\
0200200012871 & 0.72 & 2903 \\
\hline
\end{tabular}


Table 4. Cont.

\begin{tabular}{ccc}
\hline \multicolumn{3}{c}{ Most vulnerable AGEB for physical component } \\
\hline AGEB code & Vulnerability value & Exposed Population \\
\hline 0200200010610 & 0.64 & 2503 \\
0200200014789 & 0.63 & 2128 \\
0200200012320 & 0.62 & 3215 \\
\hline \multicolumn{2}{c}{ Most vulnerable AGEB for the composed index } \\
\hline AGEB code & Vulnerability value & Exposed Population \\
\hline 0000200017054 & 0.62 & 3117 \\
0200200010273 & 0.61 & 3429 \\
$020020001298 \mathrm{~A}$ & 0.59 & 4746 \\
\hline
\end{tabular}

This correlation of components has to be considered when selecting high-priority areas for the future implementation of infrastructure projects or investments to develop an overall higher resilience.

\section{Conclusions}

The complications which developing countries suffer in arid areas in managing disaster situations related to floods are mainly their economic limitations that prevent the comprehensive analysis of the area of study, the generation of hydrodynamic models and their coupling with the data of the social and economic components.

This research flexibly integrates the indicators developed by several authors with the available information. Normalization of the data obtained considers the positive or negative relationship of the variables of each component concerning the flood, allowing to identify those variables that increase the resilience of the system.

On the other hand, it is essential to mention that in this investigation, it was decided to couple the investigation with a hydrological model of the study area that had been previously developed to reinforce the physical component that is usually in developing countries: the component with the most significant lack of certainty due to the lack of previous studies. The coupled model was fed through a regional frequency analysis with a focus on the L-moments, enabling an analysis that assures the precipitation variables in different return periods, given the lack of precipitation data in the area. However, in other places that do not have previous studies of this type, they could use tools provided by remote sensing and geographic information systems to develop TWI, which can be useful for determining flood-prone areas.

The FVI results obtained allow the authorities of different government orders, urban planners, local communities, insurance companies, real estate developers and citizens in general, to have the necessary information for correct decision making, as well as to change from a reactive to proactive response in the management of disasters caused by floods, contributing to the migration of traditional planning schemes towards a sustainable urban planning process. The FVI also will enable the decision makers to identify the areas of intervention according to the priorities of stakeholders or the most vulnerable components.

Author Contributions: C.S.-B. and J.M.R.-G., "conceptualization, methodology, investigation and writing-original draft preparation". M.A.L.-B. "formal analysis, writing-review and editing". A.M.-M. "review and editing and project administration". All authors have read and agreed to the published version of the manuscript.

Funding: This research received no external funding.

Conflicts of Interest: The authors declare no conflict of interest. 


\section{References}

1. Alderman, K.; Turner, L.; Tong, S. Floods and human health: A systematic review. Environ. Int. 2012, 47, 37-47. [CrossRef]

2. Tingsanchali, T. Urban flood disaster management. Procedia Eng. 2012, 32, 25-37. [CrossRef]

3. Balica, S.; Popescu, I.; Beevers, L.; Wright, N. Parametric and physically based modelling techniques for flood risk and vulnerability assessment: A comparison. Environ. Model. Softw. 2013, 41, 84-92. [CrossRef]

4. Danumah, J.H.; Odai, S.N.; Saley, B.M.; Szarzynski, J.; Thiel, M.; Kwaku, A.; Kouame, F.K.; Akpa, L.Y. Flood risk assessment and mapping in Abidjan district using multi-criteria analysis (AHP) model and geoinformation techniques, (cote d'ivoire). Geoenviron. Disasters 2016, 3, 45. [CrossRef]

5. Gigovic, L.; Pamucar, D.; Bajić, Z.; Drobnjak, S. Application of GIS-Interval Rough AHP Methodology for Flood Hazard Mapping in Urban Areas. Water 2017, 9, 360. [CrossRef]

6. Ouma, Y.O.; Tateishi, R. Urban Flood Vulnerability and Risk Mapping Using Integrated Multi-Parametric AHP and GIS: Methodological Overview and Case Study Assessment. Water 2014, 6, 1515-1545. [CrossRef]

7. Jayasooriya, V.M.; Ng, A.W.M. Tools for Modeling of Stormwater Management and Economics of Green Infrastructure Practices: A Review. Water Air Soil Pollut. 2014, 225, 2055. [CrossRef]

8. De Vitry, M.M.; Dicht, S.; Leitão, J.P. floodX: Urban flash flood experiments monitored with conventional and alternative sensors. Earth Syst. Sci. Data 2017, 9, 657-666. [CrossRef]

9. Bodoque, J.M.; Amérigo, M.; Diez-Herrero, A.; García, J.A.; Cortés, B.; Ballesteros-Cánovas, J.; Olcina, J.; Canarelli, B.D.C. Improvement of resilience of urban areas by integrating social perception in flash-flood risk management. J. Hydrol. 2016, 541, 665-676. [CrossRef]

10. Saghafian, B.; Farazjoo, H.; Bozorgy, B.; Yazdandoost, F. Flood intensification due to changes in land use. Water Resour. Manag. 2008, 22, 1051-1067. [CrossRef]

11. Al-Ghamdi, K.; Elzahrany, R.M.-I. Impacts of urban growth on flood hazards in Makkah City, Saudi Arabia. Int. J. Water Resour. Environ. Eng. 2012, 4, 23-34.

12. Wilson, J.; Ae, J. Mississauga Evacuation View Project Dynamic Evacuation Routing View Project Watershed Urbanization and Changing Flood Behavior Across the Los Angeles Metropolitan Region; University of Southern California, GIS Research Laboratory and Center for Sustainable Cities: Los Angeles, CA, USA, 2009.

13. Azevedo de Almeida, B.; Mostafavi, A. Resilience of infrastructure systems to sea-level rise in coastal areas: Impacts, adaptation measures, and implementation challenges. Sustainability 2016, 8, 1115. [CrossRef]

14. Güneralp, B.; Guneralp, I.; Liu, Y. Changing global patterns of urban exposure to flood and drought hazards. Glob. Environ. Chang. 2015, 31, 217-225. [CrossRef]

15. Karmaoui, A.; Balica, S.F.; Messouli, M. Analysis of applicability of flood vulnerability index in Pre-Saharan region, a pilot study to assess flood in Southern Morocco. Nat. Hazards Earth Syst. Sci. Discuss. 2016, 96, 1-24. [CrossRef]

16. Ward, P.; Bouwman, A.; Bierkens, M.F.P.; Ligtvoet, W.; Winsemius, H.C.; Jongman, B.; Weiland, F.S.; Van Beek, R. Assessing flood risk at the global scale: Model setup, results, and sensitivity. Environ. Res. Lett. 2013, 8, 044019. [CrossRef]

17. Knighton, D.; Nanson, G. Distinctiveness, Diversity and Uniqueness in Arid Zone River Systems; Chapter 10. Arid Zone Geomorphology, Process, Form and Change in Drylands; John Wiley \& Sons, Ltd.: Queensland, Australia, 2011; pp. 185-203.

18. Romero-Lankao, P.; Gnatz, D.M.; Wilhelmi, O.V.; Hayden, M.H. Urban Sustainability and Resilience: From Theory to Practice. Sustainability 2016, 8, 1224. [CrossRef]

19. Amado, M.P.; Santos, C.V.; Moura, E.B.; Silva, V.G. Public participation in sustainable urban planning. Int. J. Hum. Soc. Sci. 2010, 5, 102-108.

20. Farquharson, F.; Meigh, J.; Sutcliffe, J. Regional flood frequency analysis in arid and semi-arid areas. J. Hydrol. 1992, 138, 487-501. [CrossRef]

21. Ghoneim, E.; Foody, G. Assessing flash flood hazard in an arid mountainous region. Arab. J. Geosci. 2013, 6, 1191-1202. [CrossRef]

22. Zúñiga, E.; Magaña, V. Vulnerability and risk to intense rainfall in Mexico: The effect of land use cover change. Investigaciones Geográficas 2018, 95, 1-18.

23. Cutter, S.L.; Gall, M. Hurricane Katrina: A failure of planning or a planned failure. In Naturrisiken und Sozialkatastrophen, 1st ed.; Springer Spektrum: Berlin, Germany, 2008. 
24. Dasgupta, S.; Zaman, A.; Roy, S.; Huq, M.; Jahan, S.; Nishat, A. Urban Flooding of Greater Dhaka in a Changing Climate: Building Local Resilience to Disaster Risk; World Bank Publications: Washington, DC, USA, 2015.

25. Jongman, B.; Hochrainer-Stigler, S.; Feyen, L.; Aerts, J.C.J.H.; Mechler, R.; Botzen, W.J.W.; Bouwer, L.M.; Pflug, G.; Rojas, R.; Ward, P.J. Increasing stress on disaster-risk finance due to large floods. Nat. Clim. Chang. 2014, 4, 264-268. [CrossRef]

26. Koks, E.E.; Jongman, B.; Husby, T.; Botzen, W. Combining hazard, exposure and social vulnerability to provide lessons for flood risk management. Environ. Sci. Policy 2015, 47, 42-52. [CrossRef]

27. Fernandez, P.; Mourato, S.; Moreira, M. Social vulnerability assessment of flood risk using GIS-based multicriteria decision analysis. A case study of Vila Nova de Gaia (Portugal). Geomat. Nat. Hazards Risk 2016, 7, 1367-1389. [CrossRef]

28. Dano, U.L.; Balogun, A.-L.; Matori, A.-N.; Yusof, K.W.; Abubakar, I.R.; Mohamed, M.S.; Aina, Y.A.; Pradhan, B. Flood Susceptibility Mapping Using GIS-Based Analytic Network Process: A Case Study of Perlis, Malaysia. Water 2019, 11, 615. [CrossRef]

29. Balica, S.F.; Douben, N.; Wright, N. Flood vulnerability indices at varying spatial scales. Water Sci. Technol. 2009, 60, 2571-2580. [CrossRef]

30. Balica, S.F.; Wright, N.; Van Der Meulen, F. A flood vulnerability index for coastal cities and its use in assessing climate change impacts. Nat. Hazards 2012, 64, 73-105. [CrossRef]

31. Balica, S.; Wright, N. Reducing the complexity of the flood vulnerability index. Environ. Hazards 2010, 9, 321-339. [CrossRef]

32. Surminski, S.; Oramas-Dorta, D. Do Flood Insurance Schemes in Developing Countries Provide Incentives to Reduce Physical Risks? Grantham Research Institute on Climate Change and the Environment: London, UK, 2013; No. 119.

33. Villordon, M.B.B.L.; Gourbesville, P. Community-based flood vulnerability index for urban flooding: Understanding social vulnerabilities and risks. In Advances in Hydroinformatics; Springer: Singapore, 2016; pp. 75-96.

34. Al-Zahrani, M.; Al-Areeq, A.; Sharif, H.O. Estimating urban flooding potential near the outlet of an arid catchment in Saudi Arabia. Geomat. Nat. Hazards Risk 2017, 8, 672-688. [CrossRef]

35. Salazar-Briones, C.; Hallack-Alegría, M.; Mungaray-Moctezuma, A.; Lomelí, M.A.; Lopez-Lambraño, A.; Salcedo-Peredia, A. Hydrological and hydraulic modeling of an intra-urban river in a transboundary basin using a regional frequency analysis. Tecnología y Ciencias del Agua 2018, 9, 1-29.

36. INEGI (Instituto Nacional de Estadística y Geografía). Censo de Población y Vivienda. Manual de Cartografía Geoestadística. 2010. Available online: https://www.inegi.org.mx/ (accessed on 24 February 2020).

37. Minnich, R.A.; Vizcaìno, E.F.; Dezzani, R.J. The El Niño/southern oscillation and precipitation variability in Baja California, Mexico. Atmósfera 2000, 13, 1-20.

38. García Cueto, O.R.; Tejeda Martínez, A.; Bojórquez Morales, G. Urbanization effects upon the air temperature in Mexicali, B.C., México. Atmósfera 2009, 22, 349-365.

39. Saiz-Rodriguez, A.; Salazar-Briones, C.; Lomeli-Banda, M.A. Mapa de Índice de Humedad Topográfica (IHT, Para Determinar Sitios Potenciales a Inundación en la Ciudad de Mexicali, Baja California); Obra pictórica; Número de Registro: 03-2019-121807375400-01; UABC: Baja California, NM, USA, 2019.

40. Naumann, G.; Barbosa, P.; Garrote, L.; Iglesias, A.; Vogt, J. Exploring drought vulnerability in Africa: An indicator based analysis to be used in early warning systems. Hydrol. Earth Syst. Sci. 2014, 18, 1591-1604. [CrossRef]

41. Carrao, H.; Naumann, G.; Barbosa, P. Mapping global patterns of drought risk: An empirical framework based on sub-national estimates of hazard, exposure and vulnerability. Glob. Environ. Chang. 2016, 39, 108-124. [CrossRef]

(C) 2020 by the authors. Licensee MDPI, Basel, Switzerland. This article is an open access article distributed under the terms and conditions of the Creative Commons Attribution (CC BY) license (http://creativecommons.org/licenses/by/4.0/). 